\title{
Institutional Support for Terrorist Financing Prevention ${ }^{1}$
}

\author{
By Tatjana Kovač Klemar ${ }^{*}$ \\ Miran Marelja
}

This paper focuses on the historical overview of the international framework for terrorist financing prevention, with the emphasis on the analysis of EU and non-EU institutions in charge of terrorist financing prevention and relevant to Member States such as Republic of Croatia. As part of the comprehensive analysis, the paper covers institutions' significance and historical overview of legal standards under their competence relevant for terrorism financing prevention. By analysing Resolutions, the paper presents the analyses of activities carried out by the United Nations, particularly focusing on the General Assembly and relevant Conventions, as well as the United Nations Security Council. The most important segments of EU institutions competent for adopting Directives on the prevention of terrorist financing have been analysed. It also includes analysis of the Financial Action Task Force, the Committee of Experts on the Evaluation of Anti-Money Laundering Measures and the Financing of Terrorism MONEYVAL and the Egmont Group.

Keywords: terrorist financing; MONEYVAL; Egmont Group; FATF; United Nations.

\section{Introduction}

When defining terrorism, it is important to note that there is no uniform definition applied around the world. The definition of terrorism in the Republic of Croatia is given in provisions of Article 97 of the Criminal Code. ${ }^{2}$

The issue of defining terrorism and combating both terrorism and its financing is intertwined with religion. ${ }^{3}$ Generalisation does not help in resolving the terrorism issue. Finding ideal balance between controls and sanctions aimed at terrorist groups and potential discrimination against certain peoples and ethnic and religious minorities is necessary. The analysis of the terrorist financing issue $^{4}$ has found that people who financially support terrorism are just as dangerous as those who perform acts of terrorism. ${ }^{5}$

\footnotetext{
* M.Sc., Head of SME Financial Support Sector at Ministry of Entrepreneurship and Crafts, Zagreb, Republic of Croatia. Email: tatjanakk@gmail.com.

${ }^{\star} \mathrm{PhD}$, Assistant, Department of General History of Law and State, Faculty of Law, University of Zagreb. E-mail: mmarelja@pravo.hr.

${ }^{1}$ This work has been supported by the Croatian Science Foundation under the project number UIP-2014-09-5933.

${ }^{2}$ Criminal Code, Official Gazette, No. 125/11, 144/12, 56/15, 61/15.

${ }^{3}$ Bilandžić (2014) at p. 70; Kalinić (2003) at pp. 40-41.

${ }^{4}$ Back in the 19th century, Honoré de Balzac stated (about waging war) that in order to win a war, sufficient funds to finance its total costs are of utmost importance.

${ }^{5}$ Pearl (2007).
} 
Although issues of money laundering and terrorist financing are often legally regulated in an equivalent manner, the biggest difference between money laundering and terrorist financing is the motivation. When performing money laundering, the goal is financial gain, while in case of terrorist financing, goals are non-financial. The main purpose is to get publicity for the goal and gaining political power. They also differ in amounts of money. "Money launderers" usually need to "launder" large amounts, but even small amounts of money can be sufficient for performing acts of terrorism. Terrorists, just like money launderers, aim at obtaining "clean money", but not necessarily in the cheapest way possible and are therefore prepared to pay up to $40 \%$ of value of transaction for it. ${ }^{6}$

It is clear that terrorist financing is very difficult to detect $^{7}$ before a terrorist act is performed as it often concerns relatively small amount of money.

There are two principles on which the terrorist financing legal definition is based. According to the first principle, terrorist financing includes terrorist act financing while the second principle offers a broader definition which also includes financing of all the preliminary steps needed to perform the act (even in cases when it is not performed, but only planned). Croatia's legal system has defined terrorist financing in accordance with the second principle. Terrorist financing has similar characteristics as money laundering so these two areas are often legally dealt with in a similar way, and this is also the approach implemented by the Republic of Croatia, ${ }^{8}$ which included them under the same Act. ${ }^{9}$

In secondary European Union (hereinafter: the EU) legislation, terrorist financing is defined as the provision or collection of funds, by any means, directly or indirectly, with the intention that they should be used or in the knowledge that they are to be used, in full or in part, in order to carry out any of the offences within the meaning of Articles 1 to 4 of the Council Framework Decision $2002 / 475 .^{10}$

This is also the basis of the terrorist financing definition in Croatian national legislation, that is, the Anti-Money Laundering and Terrorist Financing Act $^{11}$ (hereinafter: the AMLTFA) and the Criminal Code. ${ }^{12}$ The new AMLTFA is currently being prepared as the Republic of Croatia has a responsibility to transpose the new Directive No. 2015/849 into Croatian legislation by 26 June 2017. ${ }^{13}$

Given the importance and complexity of the issue of terrorist financing, institutions forming a part of the terrorist financing prevention system play an important role.

In accordance with the above, the first chapter covers the methodology of terrorist financing prevention within the framework of the United Nations, with special emphasis on documents of the General Assembly of the United Nations

\footnotetext{
${ }^{6}$ Mathers (2004).

${ }^{7}$ American Bar Association (2010).

${ }^{8}$ Cindori (2007) at p. 61.

${ }^{9}$ Anti-Money Laundering and Terrorist Financing Law.

${ }^{10}$ Article 1 of the Council Framework Decision (2002).

${ }_{11}$ Article 2 of the Anti-Money Laundering and Terrorist Financing Law.

${ }^{12}$ Article 82 of the Criminal Code.

${ }^{13}$ Directive (EU) 2015/849.
} 
and the Security Council. The second part focuses on EU laws and institutions, covering the following subjects: Financial Action Task Force, EU legislation (Directives in particular), Committee of Experts on the Evaluation of AntiMoney Laundering Measures and the Financing of Terrorism - MONEYVAL, a monitoring body of the Council of Europe, and the Egmont Group, an association of all Anti-Money Laundering and Counter-Terrorist Financing Offices. The final part covers institutions and associations not mainly focusing on the prevention of money laundering and terrorist financing, for which these issues represents just a part of their operations, like the World Bank and the International Monetary Fund.

In this paper we have used historical and comparative methods, using analysis and synthesis to reach conclusions regarding the significance of individual associations and institutions in the prevention of terrorist financing.

\section{Institutional Support to Terrorist Financing Prevention}

There are numerous international organisations and associations in the world dealing with anti-money laundering and combating the financing of terrorism (hereinafter: the AML/CFT). Based on their activities, they can be grouped into organisations and associations focusing solely on preventing money laundering and terrorist financing, such as the Financial Action Task Force ${ }^{14}$ (hereinafter: the FATF), the Committee of Experts on the Evaluation of Anti-Money Laundering Measures and the Financing of Terrorism - MONEYVAL (hereinafter: the MONEYVAL), a monitoring body of the Council of Europe, and the Egmont Group, and into international organisations performing terrorist financing prevention activities in parallel with their basic functions: the United Nations (hereinafter: the UN), the World Bank and the International Monetary Fund.

\section{United Nations}

World reconstruction following World War II left the UN facing various challenges, preventing the organization from focusing on the terrorism issue at first. The term terrorism is not explicitly mentioned in the UN Charter, but the phenomenon of terrorism is certainly covered by the principle of non-intervention, presented as the obligation of the States to refrain from any threat or use of force against territorial integrity or political independence of any other country. ${ }^{15}$ In the early seventies of the previous century (especially after the Munich massacre of 1972), there was a growing awareness in the UN of the danger posed by terrorist activities and internationalisation of terrorism to the preservation of international peace and security, as well as the insufficient capacity of the States

\footnotetext{
${ }^{14}$ The FATF's official name in French is Groupe d'action financière (GAFI).

${ }^{15}$ Art. 2, paragraph 4 of the UN Charter.
} 
to independently combat international terrorism. ${ }^{16}$ Despite the awareness of the need for UN to comprehensively approach the issue, preparation of a convention with a wider scope which would cover terrorism in a more comprehensive way failed due to the Cold War division, since the very definition of terrorism ${ }^{17}$ proved to be an insurmountable stumbling block, particularly due to the developed countries' reluctance to leave out the struggle of colonial nations against foreign masters from terrorist activities. ${ }^{18}$ The evolution of international terrorism during the 1990s reveals shortcomings of the previous legal framework built primarily on sanctioning perpetrators through multilateral international agreements and adaptation of individual States' criminal laws to include new forms of terrorist acts. One gets the impression that for the international community "terrorism is allowed under certain assumptions" despite numerous resolutions of the General Assembly, followed by those of the Security Council, on the threat of international terrorism. ${ }^{19}$ The above is not surprising, given that the content of the resolutions was significantly shaped and toned down by political reasons, with former resolutions by $\mathrm{UN}$ authorities, despite their political and moral value, being of a non-binding nature to the Member States (they were simply recommendations). ${ }^{20}$

As more significance is given to the prevention as an efficient form of counter-terrorism activities, an increasing amount of attention is paid to preventing the financing of terrorist organisations and their activities, primarily by regulating existing national and international financial institutions. ${ }^{21}$ Even though terrorist attacks can be performed using smaller funds, ${ }^{22}$ financial

\footnotetext{
${ }^{16}$ Internationalisation of the terrorism phenomenon during the League of Nations (1934) following the assassinations of the Yugoslavian King Alexander and French Minister of Foreign Affairs Barthou in Marseilles, triggered the first attempts to prevent terrorism on the international level. The complexity of the issue led to the establishment of a specialised League body, the Counter-Terrorism Committee, and the preparation of two convention drafts aimed at the prevention and sanctioning of terrorism, that is, establishment of a criminal court competent for sanctioning acts of international terrorism. Unfortunately, the conventions did not see the light of day. See Saul (2006) at pp. 80-95.

${ }^{17}$ Initially connected to terror in the times of French Revolution, it meant measures taken by the government in order to generate fear as a means of forcing its own citizens into obedience. See Green (1979) at pp. 129, 134; Merriman (2009).

18 Recognition of the right of nations to self-determination leads towards legalization of (armed) activities undertaken to that end, but the complexity of the problem is clearly illustrated by the 1987 statement made by the former UN Secretary General Perez de Cuellar who, speaking in the context of fighting the PLO and SWAPO, warned about sometimes being difficult to distinguish where terrorism ends and the struggle for independence begins. Romanov (1990) at p. 295.

${ }^{19}$ Romanov (1990) at pp. 289, 301.

${ }^{20}$ Unlike multilateral international conventions which are only binding for the parties to the agreement, General Assembly resolutions are not legally binding for Member States. This claim also applies to the Security Council resolutions unless the Council acts in accordance with Chapter VII of the Charter. See Amos (1983) at p. 504.

${ }^{21}$ Joyner's remarks about the resistance to terrorism regulation in the international humanitarian law are interesting. See Joyner (2004) p. 242.

${ }^{22}$ Simser states that in 2000 , terrorists only spent about $\$ 10,000$ for the terrorist attack on the US navy ship USS Cole, and the same amount for the Madrid attack in 2004. On the other
} 
support is crucial for building and maintaining a terrorist network as well as for terrorist training. Funds available to terrorist organisations often play a crucial part in the selection of their targets. ${ }^{23}$ This is why UN's efforts are aimed at creating a normative framework for counter-terrorist financing and also at establishing subsidiary bodies in the Organization itself to improve the operation of UN's two political organs - the General Assembly and the Security Council. On the other hand, significant efforts are being made to build an international network through cooperation with specialised UN institutions, within the framework of their authority, regional and sub-regional organisations and other international organization, taking into consideration the contribution of a number of international non-governmental organisations, as well as private sector entities. $^{24}$

\section{General Assembly}

The General Assembly, often at the proposal of the Sixth (Legal) Committee, its permanent subsidiary body, adopted a series of resolutions, including two declarations, aimed at forming counter-terrorism measures. The Assembly's contribution to the establishment of a legal counter-terrorism framework is also visible in the preparation of counter-terrorism international conventions. ${ }^{25}$ Due to the aforementioned events of the 1972 Olympics, the General Assembly was for the first time faced directly with terrorism issues, resulting in a series of measures for combating international terrorism, such as taking "appropriate measures", ${ }^{26}$ being proposed to the Member States alongside the proposal to join the existing applicable international conventions. Even though the controversial issue of terrorism causes was originally entrusted to the competence of the Sixth Committee, the Assembly also established the Ad Hoc Committee on International Terrorism, which spent years unsuccessfully tackling the definition and causes of international terrorism. ${ }^{27}$

The Assembly's attitude towards terrorism gradually intensified, as can be seen in the tone of its resolutions, but although "deep concern" about the suffering of innocent victims ${ }^{28}$ soon became "unreserved condemnation of all acts of international terrorism", ${ }^{29}$ it was not until 1983 that the States were reminded of the obligation to refrain from "organizing, instigating, assisting or

hand, the terrorist attack in London in 2005 cost only $\$ 15,000$. Moreover, the 9/11 New York attack in 2001 was performed with less than $\$ 500,000$. See Simser (2011) at p. 334.

${ }^{23}$ Ramzi Yusef, the organiser of the WTC attack of 1993 specified the lack of financial funds as the main reason a much less powerful bomb than initially planned was used. Levitt (2002) at p. 2 as referred to by Raphaeli (2003) at p. 60.

${ }^{24}$ Banićević (2013).

${ }^{25}$ Kalliopi (2006) at p. 49.

${ }^{26}$ The title of Resolution 3034 (XXVII, 1972) contains an important determinant of terrorism an aspiration to effect radical changes by performing acts of terrorism.

27 The Assembly later used ad hoc committees primarily for preparing drafts of various counterterrorism conventions. Kalliopi (2006) at p. 51.

${ }^{28}$ In general, terminology from A/RES 3034 (XXVII 1972) is used in Resolutions 31/102 (1976), 32/147 (1977), and 34/145 (1979).

${ }^{29}$ A/RES 34/145 (1979). 
participating" in terrorist acts against other States, ${ }^{30}$ while two years later terrorism is referred to as a "criminal activity" which includes "all acts, methods and practices of terrorism" 31 while explicitly mentioning terrorism prevention. ${ }^{32}$ The Declaration on Measures to Eliminate International Terrorism from 1994 substantially elaborates on prevention and its role in combating terrorism, and points to the connection between terrorism and drug trafficking, arms trade, money laundering and smuggling of nuclear and other hazardous materials. Existing legal instruments for the prevention of terrorism are deemed inadequate and the Declaration also calls for normative regulation of terrorism aspects not covered by the existing regulations. ${ }^{33}$

Shortly after that, the Assembly clearly called for the States to take measures which would, as part of changes to the internal legislative framework, prevent terrorist and terrorist organization financing, whether the terrorists and terrorist organisations were financed directly or indirectly, through cover-up operations (organisations aimed at reaching charitable, social or cultural goals) or through other criminal organisations primarily focused on arms trade, drug trafficking or extortion. ${ }^{34}$ In addition to again requesting termination of state-sponsored terrorism, while also directly mentioning financing of terrorist activities, the States' attention was drawn to the need for taking measures within the framework of their legislation to prevent and stop international money flows intended for terrorism financing. It is clear that such a measure can yield noticeable results only with a much greater level of international cooperation and further construction of the international legal framework. ${ }^{35}$ Faced with the urgent need to improve international cooperation regarding the prevention of terrorist financing, the General Assembly entrusted the Ad Hoc Committee with creating a $\mathrm{draft}^{36}$, which in 1999 finally led to the adoption of the Convention for the

\footnotetext{
${ }^{30}$ From A/RES 38/130 (1983). The obligation to recognise sovereignty of another country is re-emphasised in the General Assembly resolution 39/159 (1984) condemning state-sponsored terrorism, associating it with aggression and directly endangering the possibility of peaceful relations between the States. A/RESes 38/130 (1983) and 39/159 (1984).

${ }^{31} \mathrm{~A} / \mathrm{RES}$ 40/61 (1985) directly warns of the need to preserve the adopted human rights protection standards and finally specifies the request for adoption of "internal measures" by harmonizing the States' legislation with their international obligations in combating terrorism.

${ }^{32}$ A/RES 40/61 (1985) primarily through the exchange of relevant information between the countries, but the content of the prevention concept is not determined. Compare with A/RES 42/159 (1987). See Romanov (1990) at p. 298.

${ }^{33}$ See paragraphs $7,9 \mathrm{c}, 9 \mathrm{~d}$ of the Declaration.

${ }^{34}$ Item 3(f) of A/Res 51/210 (1996).

${ }^{35}$ A/RES 51/210 (1996). The General Assembly's Supplement to the Declaration on measures for combating terrorism expressly describes terrorist financing, alongside terrorism planning and encouraging, as contrary to the principles and purposes of the Organisation itself. Similarly, the Global Counter-Terrorism Strategy from 2005 sees terrorism as one of the most dangerous threats to international peace and security.

${ }^{36}$ As part of the supplement to the existing international legal instruments, the Committee's task list included the development of the legal framework against terrorist financing, which also soon covered cooperation and coordination of cooperation with specialised agencies, and regional organisations, as well as drafting of a convention which would substantially incorporate various aspects of combating terrorist financing. See A/Res 51/210 (1997), 53/108 (1999), 55/108 (1999); Johnson (2000) at pp. 268-269.
} 
Suppression of the Financing of Terrorism. ${ }^{37}$ When defining funds, ${ }^{38}$ the Convention relies on the aut dedere aut punire principle, meaning that Member States undertake to prosecute direct or indirect financing of terrorist acts on their territory, ${ }^{39}$ or to extradite perpetrators to the party to the Convention looking for such perpetrators for acts sanctioned by the Convention. ${ }^{40}$

At the end of the last millennium, due to the escalation of international terrorism, it became clear that more decisive steps were needed, so the Security Council went on to take precedence within the Organization, subsequently leading to the establishment of several new subsidiary bodies within the Organization itself. However, let us also mention what is today considered as the backbone of counter-terrorism - the Global Counter-Terrorism Strategy, adopted by the Assembly. ${ }^{41}$ The Strategy (representing a kind of synthesis of previous efforts) starts from preventing all forms of support for terrorism, including financing of terrorist activities and organisations, within the States and through cooperation at regional and global levels. This particularly emphasised the UN's coordinating role in the international community. It was intended as four sets of measures, with the prevention of terrorist financing (in form of state sponsorship or privately sponsored terrorism) representing the basis of one of the sets, ${ }^{42}$ which is also closely linked to money laundering, illegal arms trade and drugs trafficking, as well as smuggling of weapons of mass destruction. ${ }^{43}$ To this end, the need for intergovernmental cooperation and coordination is emphasised, alongside advocating for the establishment of the International Centre for Counter-Terrorism, responsible for the implementation of existing recommendations, guidelines or best practices in national legislation, mostly having in mind FATF's 40 recommendations ${ }^{44}$ and 9 special recommendations. ${ }^{45}$ With emphasis on the supervisory role of the Security Council in fulfilling the obligations regarding counter-terrorism assumed by the States, ${ }^{46}$ the awareness of the need for institutional ramification of international cooperation led to the invitation to the International Monetary Fund and the World Bank in order to improve cooperation between these

\footnotetext{
${ }^{37}$ The Convention was adopted by the A/Res 54/109 (1999). For more information about the Republic of Croatia's joining the aforementioned Convention, see the Official Gazette, International Agreements, No. 16/03.

${ }^{38}$ For more information on what the term "funds" covers, see A/RES 54/109, Article 1.

${ }^{39}$ Laid down in Article 2 of the Convention. A/RES 54/109, Article 2, 13, 14; Johnson (2000) at p. 269.

${ }^{40}$ Finally, the Convention adopted a whole range of measures to be implemented into domestic laws, aimed at detecting the origin of money and transaction transparency.

${ }^{41}$ The Global Strategy was adopted by A/RES 60/288 (2006), and, alongside the content of previous resolutions dealing with terrorism, it is based on the World Summit Outcome in the A/RES 60/1 (2005).

${ }^{42}$ A/RES 60/288 (2006), items II-1 and II-2.

${ }^{43}$ The strategy lists weapons of mass destruction even though it does not mention the term itself. A/RES 60/288 (2006), item II-5.

${ }^{44}$ Recommendations regarding money laundering prevention, in the framework of FATF. A/RES 60/288 (2006), item II-10.

${ }^{45}$ Recommendations regarding terrorist financing prevention, in the framework of FATF. A/RES 60/288 (2006), item II-10.

${ }^{46}$ Items 86-90. World Summit Outcome in the A/RES 60/1 (2005).
} 
organisations and the States, including providing the States with necessary assistance to meet their international obligations, ${ }^{47}$ as well as aiding further development of the effectiveness of the legal framework for combating money laundering and terrorist financing. ${ }^{48}$

Continuous Strategy analyses and supplements sought to correct the identified shortcomings and improve its implementation. The first supplement in 2008 confirmed the establishment of the Working Group. It was conceived as a body for providing necessary assistance to the States regarding the implementation of measures from the Strategy, especially with respect to the exchange of relevant information ${ }^{49}$ and coordination of the work of its 38 Member States. The working group soon became an indispensable support to the Assembly. ${ }^{50}$ The importance of the exchange of different country practices in implementing measures was also recognised ${ }^{51}$ and, with their improvement in mind, non-governmental international organisations were also invited to contribute to the implementation of the Strategy. ${ }^{52}$ Recognizing the problems of insufficient technical assistance to the States and being aware of specific counter-terrorism legal knowledge (especially in the prevention of its financing), the General Assembly entrusted the UN Office on Drugs and Crime with preparing a technical assistance programme. ${ }^{53}$ Using even harsher rhetoric and strong condemnation of terrorism in 2012, the responsibility of Member States for implementing the measures from the Strategy was further emphasised. ${ }^{54}$ The goal of pointing out prevention and combating terrorist financing was to make measure implementation easier for the States and to develop a system of aid within the UN. ${ }^{55}$ The fourth review of the Strategy called for the States to prevent abuse of non-profit and charitable organisations by terrorists and for terrorists, ${ }^{56}$ and also to prevent attempts of their misuse by terrorists. ${ }^{57}$

\footnotetext{
${ }^{47}$ Assistance to the States upon joining the basic international counter-terrorism conventions and the International Convention for the Suppression of the Financing of Terrorism is planned. General A/RES 62/71 (2008).

${ }^{48}$ Item III- 8 of the Global Strategy. The strategy also invites a number of UN specialised agencies, such as the World Health Organisation, the International Maritime Organisation etc., and the International Organisation of Atomic Energy, to contribute to the fight against terrorism on matter falling within their competence. See A/RES 62/272 (2008).

${ }^{49}$ A/RES.62/272 (2008). Initiated activities will be completed by A/RES 64/235 (2010).

50 A number of bodies and organisations such as the Committee on Counter-Terrorism, the World Bank, the International Monetary Fund, Interpol, etc. operate as part of the working group. A/RES 64/177 (2010).

${ }^{51}$ The fourth review of the Strategy from 2010, A/RES 64/297 (2010).

52 A/RES 64/297 (2010).

${ }^{53}$ A/RES 66/178 (2011).

${ }^{54}$ Third amendment to the Global Strategy. A/RES 66/282 (2012).

55 A/RES 66/282 (2012).

${ }^{56}$ This measure is in line with the 2013 General Assembly's calls for immediate analysis of the impact of existing international legal instruments for the prevention, control and elimination of terrorism, from which it is clear that previously adopted instruments left a certain part of the terrorism problem outside the legal framework. See A/RES 68/119 (2013).

${ }^{57}$ A/RES 68/276 (2014). Also, the problem of misuse was also observed by the FATF and due consideration was given to non-governmental, non-profit and charitable organisations in the review of Recommendations. Shortly after the review, the Security Council drew the States'
} 


\section{Security Council}

The Security Council exhibited a growing interest in international terrorism in the second half of the 90s, and in 1996, the Council recognised this phenomenon as a serious threat to international peace and security. ${ }^{58}$ However, although the Council continuously condemned the attacks in its resolutions, calling for the need to strengthen international cooperation in combating terrorism, the very nature of resolutions as the so-called soft law instruments offering recommendations to the States, neither obliged the UN Member States nor generally requested changes in the Member States legislation. ${ }^{59}$ With regard to combating terrorism, Council Resolution 1267 significantly deviated from the established practices as it was adopted by the Council invoking Chapter VII of the Charter ${ }^{60}$ making it binding to all members of the Organization. ${ }^{61}$ Focused on the Taliban regime sanctioning, the Resolution contains an obligation for the States to freeze funds and other financial resources, including funds derived from assets owned or, directly or indirectly, controlled by the Taliban. ${ }^{62}$ The Sanctions Committee was established in order to facilitate the implementation of the planned measures and particularly the identification of persons covered by this measure, as well of assets under the asset freeze obligation. ${ }^{63}$

The specified Committee, the Security Council's subsidiary body, comprised of representatives of all Council members, was designed as a link between the Council and UN Member States in the development and implementation of measures specified in this Resolution, the Committee collects reports on implementation from the States, and in return, it provides them with aid in form of recommendations and also reports to the Council on the States' progress and on cases of avoiding their obligations. The Council required the States to also appropriately sanction all violators of those measures, ${ }^{64}$ while Resolution 1333 was even more clear about sanctioning participation in the financing, planning, assisting and preparing terrorist acts or activities, particularly emphasizing the prohibition of direct or indirect logistical support to the Taliban in form of

attention to the solutions contained in the Recommendations. See S/RES 2129 (2013) and S/RES 2161 (2014).

${ }^{58}$ S/RES 1044 (1996). Since the terrorist bombings in Tanzania and Kenya in 1998, the focus has shifted from state-sponsored terrorism to newly evolved forms of terrorist organisations.

${ }^{59}$ Other than offering condemnation for terrorist attacks, the Security Council dealt with trivial issues up until S/RES 1267 (1999). See Stiles and Thayne (2006) at p. 158.

${ }^{60}$ Article 25 and 48 of the UN Charter. For legal consequences of invoking Chapter VII regarding terrorist attack condemnation see Durrieu (2013) at pp. 113-114.

${ }^{61}$ Resolutions adopted pursuant to Chapter VII of the UN Charter regarding combating terrorism oblige the States to protect persons and assets from terrorist attacks. See Joyner (2004) at p. 243.

${ }^{62}$ With exceptions provided in this Resolution. The specified funds can be used if the Committee previously approved an exception for humanitarian reasons. S/RES 1267 (1999).

${ }^{63}$ The Committee was founded exclusively for the implementation of sanctions to the Taliban regime and persons connected to this regime. As a matter of fact, it is due to the States' obligations to implement measures from the Resolution that a supervisory mechanism is needed (ultimately, that mechanism is the Security Council).

${ }^{64}$ The term "violators of measures" means both natural and legal persons. 
equipment provision, sale or delivery of military vehicles, weapons and other related resources, and training and recruitment of soldiers for the Taliban regime. States are obliged to prevent both their own citizens and foreign nationals, if they are in their territory, from engaging in terrorism financing. The provided sanctions also apply to the funds available to Osama bin Laden and funds of individuals and organisations related to Osama bin Laden, including and especially referring to the terrorist organization Al-Qaida. ${ }^{65}$ The Sanctions Committee was requested to create the Consolidated List, which would include people and organisations linked to the Taliban regime, Osama bin Laden and Al-Qaida, and further elaborated on the issue of humanitarian organisation activities, resulting in a separate list of organisations providing aid to Afghanistan people through charitable activities. ${ }^{66}$ Overseeing implementation of measures imposed by Resolution 1333 was entrusted to the existing Sanctions Committee, with the Committee of Experts being established as a subsidiary body. ${ }^{67}$ In addition to proposing progressive development of the existing measures, the mechanism would primarily oversee implementation of the imposed measures regarding prohibition of weapons trade, measures regulating terrorist-related activities such as financing of terrorism, arms trade, money laundering, illegal financial transactions and drug trafficking.

To minimise the possibility of misidentification and/or erroneous connection of people and organisations, leading to their subsequent inclusion on the Consolidated List, the States were in 2004 required to also submit necessary supporting documents when updating the list with new names, ${ }^{68}$ while the Sanctions Committee also got a Supervisory Body. Although it established the connection of persons and organisations with terrorism, and their connection with persons and organisations referred to as terrorist, as a criterion for including them on the Consolidated List, ${ }^{69}$ and even though the States were for the first time called to adopt international standards, ${ }^{70}$ significant deficiencies in the system of inclusion to and removal from the list were detected. To this end, the Council introduced changes in the procedure of inclusion to and removal from the list. It is also important to note the constant upgrading of: set criteria $^{71}$ strengthening of the Counter-Terrorism Committee's role in the

\footnotetext{
${ }^{65}$ The Council shows awareness regarding the direct link between the revenues generated in the Afghan opium trade and the financing of the Taliban terrorist activities. S/RES 1333 (2000); Pedić (2012) at p. 63.

${ }^{66}$ These are verified government and private organisations for control of cover-up operations disguised as humanitarian organisations. S/RES 1333 (2000).

${ }^{67}$ S/RES 1363 (2001).

${ }^{68}$ To this end, the States were called to notify individuals and organisations of being on the list. S/RES 1526 (2004).

${ }^{69}$ For more information about the term "terrorist financing" see S/RES 1617 (2005).

${ }^{70}$ S/RES 1617 (2005) refers to the standards formed into Recommendations of the FATF. Note that S/RES 1617 (2005) was adopted pursuant to Chapter VII of the UN Charter.

${ }^{71}$ The States were requested to adopt supplemented FATF standards, with emphasis on Recommendation 6 regulating adoption of the best practices as a measure of terrorist financing prevention (construction of a preventive system), while the scope of preliminary investigation and investigative activities was expended, with the probable cause standard being used to
} 
unfreezing of funds ${ }^{72}$ and the establishment of the Office of the Ombudsman for the purpose of prevention of misuse through independent control of inclusion on and removal from the list.

In 2011, the Council decided to separate the sanctions regime against AlQaida and the Taliban, ${ }^{73}$ resulting in, based on the Sanctions Committee from Resolution 1267, the formation of the Al-Qaida Sanctions Committee and connected persons and entities to whom the Al-Qaida Sanctions List was entrusted, containing only names of individuals, companies and entities connected to this terrorist organisation. ${ }^{74}$ This list also included terrorist organisations the Islamic State of Iraq and the Levant (hereinafter: ISIL) and the Al-Nusra Front (hereinafter: ANF) due to their connection with Al-Qaida, but these organisations were condemned individually in numerous Council resolutions. ${ }^{75}$ In addition to the Sanctions List for Al-Qaida, a new list consisting of only the Taliban and associated individuals, groups, businesses and entities was created. The management of this list was entrusted to a new Security Council Sanctions Committee established by Resolution $1988 .^{76}$ Due to further amendments, the States undertook the obligation to criminalise persons who financially help ISIL, ${ }^{77}$ and the Al-Qaida Sanctions Committee was again renamed, becoming the ISIL and Al-Qaida Sanctions Committee, with the accompanying updating of the content and terminology in the sanctions list. ${ }^{78}$ Regardless of the above changes in terminology, we should mention a number of problems in data collection since some States fully or partially ignored their obligations under the binding resolutions. ${ }^{79}$

Another important document is the unanimously adopted Council Resolution 1373, significantly harmonizing international cooperation in terms of preventing and combating terrorism, partly through States' obligation to assist other States in preliminary investigation or investigation procedure in order to gather proof on financing and assisting terrorist acts. ${ }^{80}$ Not only did it sanction statesponsored terrorism, but it obliged States to prevent and combat terrorist act financing, and immediately freeze assets of persons (natural or legal) participating

determine financial measures. See Financing of the Terrorist Organisation Islamic State in Iraq and the Levant (2015); Emerging Terrorist Financing Risks (2015); Durrieu (2013) at pp.167-8.

${ }^{72}$ S/RES 2083 (2012).

${ }^{73}$ S/RES 1988 (2011) and S/RES 1989 (2011).

${ }^{74}$ Pursuant the S/RES 1267 (1999) and S/RES 1989 (2011). See also the Anti-Money Laundering Office (2011) and Pedić (2012), at p. 63.

75 ISIL and ANF, also known as Jabhat Al-Nusra, are terrorist branches of Al-Qaida in Syria. S/RES 2161 (2014) and S/RES 2170 (2014) in which the Council accuses ISIL of terrorist acts and numerous international humanitarian law violations, as well as of a new problem in form of funding and other forms of sponsorship to recruit foreign nationals to terrorist groups and allow them to travel to foreign States to fight alongside terrorists. S/RES 2178 (2014).

${ }^{76}$ S/RES 1988 (2011).

${ }^{77}$ S/RES 2242 (2015).

${ }^{78}$ The Sanctions List for ISIL and Al-Qaida was created. See S/RES 2253 (2015).

${ }^{79}$ S/RES 2253 (2015) reminding the States of their obligations under previous S/RES 1267 (1999), S/RES 1989 (2011), and S/RES 2199 (2015).

${ }^{80}$ S/RES 1373 (2001). 
in terrorist activities, ${ }^{81}$ as well as to prohibit their financing or aiding and, for this purpose, make the necessary changes and amendments to their criminal legislation in order to appropriately sanction those individuals, groups, businesses and entities associated with them. ${ }^{82}$ Moreover, criminalization of financing included donations or funds intended, directly or indirectly, with the intention or knowledge, for the financing of terrorism. ${ }^{83}$ Some new sources of terrorist organisation funding such as kidnappings for ransom money or illegal exploitation of natural resources for funding terrorism were included later on. ${ }^{84}$

The Counter-Terrorism Committee of the Security Council, established by this Resolution and made up of representatives of all members of the Council, was designed to provide assistance to the States in strengthening their ability to oppose international terrorism, but also served as a form of UN's response to the terrorist attacks of September 11, 2001 and the proliferation of international terrorism. ${ }^{85}$ The Council calls on all States to inform the Counter-Terrorism Committee of the difficulties encountered in implementing the measures from Resolution 1373, but also requests from the Committee to formulate the best methods to help the States and, to that end, to pinpoint the most successful national mechanisms for implementation and develop a model law as a recommendation to the States. ${ }^{86}$ The Committee assesses the degree of implementation of binding measures for each Member State, paying particular attention to national legislation changes of individual States to comply with Resolution requirements, while distinguishing normative activities aimed at criminalisation of terrorism in general from measures taken solely for criminalisation of terrorist financing. ${ }^{87}$

The Declaration on Combating Terrorism from 2003 further emphasised the role of the Counter-Terrorism Committee in reviewing States' reports and providing assistance in form of Committee recommendations when creating the best measures and standards for combating terrorism. ${ }^{88}$ This opens way to the standardisation of measures for preventing terrorist financing, not just through mere aggregation of measures from previous resolutions, but also through

\footnotetext{
${ }^{81}$ With regard to the responsibility of States for not complying with the measures of S/RES 1373 (2001) and Proulx (2012) at p. 104.

${ }^{82}$ The resolution is directly aimed at individuals and legal entities that finance the commission of terrorist acts. Another novelty was the requirement for withholding a safe haven from executors and accomplices of terrorist activities, or persons who plan and finance such activities, alongside the existing obligation of their prosecution. See Joyner (2004) at p. 242 and Combs (2006) at p. 219.

${ }^{83}$ Compare with later S/RES 1805 (2008) and S/RES 2082 (2012).

${ }^{84}$ S/RES 2133 (2014), S/RES1373 (2001), S/RES 2160 (2014), S/RES 2199 (2015), S/RES 2160 (2014), S/RES 2199 (2015) and S/RES 2253 (2015).

85 The urgency of the Council's reaction to the terrorism issue is evident from the fact that Member States were not given an opportunity to participate directly in the drafting of the Resolution, that is, they were not able to submit their proposals, so, according to Stiles, at a special session of the General Assembly devoted to terrorism, Tanzania expressed the opinion that the Security Council exceeded its jurisdiction by S/RES 1373 (2001). See Stiles and Thayne (2006), note 62, p. 158.

${ }^{86}$ Security Council resolution 1373 (2001).

${ }^{87}$ Stiles and Thayne (2006) at p. 159.

${ }^{88}$ The cooperation of regional and sub-regional organisations and the Counter-Terrorist Committee was particularly emphasised. See S/RES 1456 (2003).
} 
systematic elaboration of their synergistic effect, ${ }^{89}$ including measures for preventing misuse of non-profit organisations. ${ }^{90}$ To provide more efficient assistance to the States in implementing measures, and also to achieve better control of their implementation, the need for the Counter-Terrorism Committee to visit the States was addressed (2004), and for the purpose of cooperation both with other bodies within the UN and with international organisations outside the Organisation system, ${ }^{91}$ the Counter-Terrorism Committee was structurally reorganised. The existing plenary body consisting of the Security Council members was joined by the special Bureau and the Executive Directorate of the Counter-Terrorism Committee as a subsidiary Bureau body was formed. ${ }^{92}$ In order to improve the Committee's work, the Executive Directorate took over studying the States' level of compliance and the effect of measure implementation. ${ }^{93}$

Institutional development started increasingly focusing on the nonharmonisation of bodies in the UN system and the problem of coordination of their work, especially with regard to unnecessary duplication of tasks of different bodies, but also on the States' obligations of a technical nature, boiling down to repeatedly submitting the same reports, also emphasising shortcomings in the Organisation's infrastructure. In order to build an effective system and enable more efficient freezing of assets of individuals and organisations associated with terrorism, the Security Council established a Working Group for the implementation of Resolution 1566 (composed of all members of the Council), dealing with practical measures for combating individuals, terrorist organisations and related persons (not marked by the Sanctions Committee, therefore being absent from the Sanctions List). ${ }^{94}$ Also, in the framework of providing assistance to the Sanctions Committee, the Analytical Support and Sanctions Monitoring Team quickly built connections with the private sector, including relevant financial institutions, in order to improve applicability of measures on freezing of funds intended for terrorist financing. ${ }^{95}$ With the amendments to the procedure for inclusion to and removal from the Sanctions List, this body soon started providing necessary assistance to the Office of the Ombudsman within its jurisdiction, so with further development of criteria for inclusion to and removal from the list, it also started focusing more on the experience and knowledge of private sector entities in combating terrorist financing, primarily through

${ }^{89}$ S/RES 1526 (2004), S/RES 1617 (2004), and the further development of sanctioning mechanisms in S/RES 1730 (2006).

${ }^{90}$ S/RES 1526 (2004).

${ }^{91}$ S/RES 1535 (2004) proposes that these visits be organised in cooperation with other international, regional and sub-regional organisations. See Combs (2006) at p. 219.

92 The Counter-Terrorism Committee Executive Directorate was established by S/RES 1535 (2004). For more information about the Directorate see Home/United Nations; Biersteker, Eckert and Romaniuk (2008) at p. 238.

${ }^{93}$ S/RES 1963 (2010), S/RES 1373 (2001) and S/RES 1624 (2005).

${ }^{94}$ S/RES 1566 (2004).

95 Annex II to the S/RES 1735 (2006). Tasks of the Analytical Support and Sanctions Monitoring Team were updated by S/RES 1822 (2008), making this body an essential mechanism in the implementation of the Global Counter-Terrorism Strategy. Council S/RES 1735 (2006), S/RES 1822 (2008) and S/RES 1904 (2009). 
identifying terrorist organisations and their cover-up operations by sharing information. ${ }^{96}$

\section{Financial Action Task Force}

Financial Action Task Force (previously abbreviated: the FATF) is an international organisation focusing on money laundering and terrorist financing prevention. It was established at the G7 Summit ${ }^{97}$ held in Paris aimed at combating money laundering. Following the events of September 11, 2001, the FATF has focused also on combating terrorist financing. The FATF is not a permanent organisation, its mandate needs to be extended. In the last report from 2012, the FATF's mandate was extended until 2020. Its meetings are held 3 times a year.

The FATF currently consists of 36 members, 34 of which are States and 2 are regional organisations (the European Commission and the Gulf Co-operation Council). Republic of Croatia is not a member of the FATF. The FATF's current observers are Malaysia and Saudi Arabia, alongside a number of organisations only treated as observers. ${ }^{98}$ The accession of individual countries/ organisations into membership or observer status is regulated by specific policies.

The FATF intergovernmental body ${ }^{99}$ was established to perform the following tasks: publishing standards for combating money laundering and terrorist financing (in form of Recommendations); assessing how the antimoney laundering and counter-terrorist financing system in each country works and determining deficiencies posing a threat to the financial sector of each country and shortcomings which need to be corrected at the legislative and operational levels; publishing a list of non-cooperative States (States which do not implement measures to prevent money laundering and terrorist financing in an appropriate manner); monitoring and analysing the most recent modalities of money laundering and terrorist financing and publishing Reports on the recent modalities in order to warn the global financial sector of new risks or increased existing risks of a particular modality of money laundering and terrorist financing.

The adoption of Recommendations, based on which further legal regulations regarding money laundering and terrorist financing prevention are adopted, was emphasised as the most important task. Recommendations are not binding, but they represent the source for the best international practices. Recommendations are not to be transposed into individual States' legislation because of their descriptive nature and they provide flexibility of implementation.

The first recommendations, covering only money laundering, were adopted in April of 1990 and the first recommendations also regulating terrorism financing

\footnotetext{
${ }^{96}$ S/RES 1989 (2011), S/RES 2083 (2012) and S/RES 2253 (2015).

97 The G7 countries are: Canada, France, Germany, Italy, Japan, the United Kingdom and the United States of America.

${ }^{98}$ Available at: http://www.fatf-gafi.org/about/membersandobservers/ visited on 17 January 2016.

${ }^{99}$ Cindori (2008) at p. 174.
} 
were adopted in October of 2001 as Eight Special Recommendations. The specified recommendations were amended by the ninth recommendation in October of 2004 and that is when they were renamed into the Nine Special Recommendations. ${ }^{100}$

The Nine Special Recommendations cover the following topics: ratification and implementation of the instruments (UN Declaration), criminalisation of terrorist financing and the related money laundering, freezing and confiscating of terrorist assets (of individuals and organisations), reporting of suspicious transactions related to terrorism, international cooperation related to terrorism, control of alternative/informal value transfer systems (usually Hawala), noncash payments, non-profit organisations and carriers of cash. ${ }^{101}$

When the recommendations were implemented, it was noticed that some recommendations may similarly be applied to combating money laundering and terrorist financing, and it was decided that the previous 40 Recommendations (on Anti-Money Laundering) and 9 Special Recommendations on Terrorist Financing should be unified, which was done in 2012. ${ }^{102}$ The new Recommendations, in addition to combating money laundering and terrorist financing, regulated two more areas: corruption and proliferation of weapons of mass destruction (both closely related to terrorist financing). The new Recommendations also emphasised the exchange of information, which is crucial especially in issues of terrorist financing.

Even though a vast majority of Recommendations from 2012 can interchangeably refer to money laundering and financing of terrorism, the relevant Recommendations particularly focused on financing of terrorism are in section $\mathrm{C}$ "Financing of terrorism and financing the proliferation of weapons of mass destruction". Section C includes 4 recommendations regarding the criminal act of financing terrorism, targeted financial sanctions in relation to terrorism and its financing, targeted financial sanctions in relation to the financing of the proliferation of weapons of mass destruction and non-profit organisations.

Based on their findings and assessments, the FATF issued a list of countries (non-cooperative countries), divided in two groups: countries against which actions should be initiated to protect the international financial system and countries which have made some progress in the area of combating money laundering and terrorist financing, but the general public is warned to approach doing business with these countries with caution. ${ }^{103}$

One of the FATF's important tasks includes publishing Reports about the latest modalities of terrorist financing. The specified Reports explain FATF recommendations relevant for terrorist financing. Recent reports include: Terrorist Financing: FATF Report to G20 Leaders - actions being taken by the

\footnotetext{
${ }^{100}$ IX Special Recommendations (2014).

${ }^{101}$ Kovač Klemar (2012) at p. 19.

${ }^{102}$ International standards on combating money laundering and the financing of terrorism \& proliferation, The FATF Recommendations (2012).

${ }^{103}$ Zacząć działać już z dostawcami loterii on-line w Internecie - Tu trzeba uważać.
} 
FATF ${ }^{104}$ Emerging Terrorist Financing Risks, ${ }^{105}$ Money laundering and terrorist financing risks and vulnerabilities associated with gold, ${ }^{106}$ Financing of the Terrorist Organisation Islamic State in Iraq and the Levant, ${ }^{107}$ Financial flows linked to the production and trafficking of Afghan opiates, ${ }^{108}$ Risk of terrorist abuse in non-profit organisation, ${ }^{109}$ Virtual Currencies: Key Definitions and Potential AML/CFT Risks ${ }^{110}$ and Money laundering and terrorist financing through trade in diamonds. ${ }^{111}$

\section{EU Institutions}

While the FATF Recommendations are non-binding, EU Directives on combating money laundering and terrorist financing are binding. Directive 2005/60/EC was the last one transposed into Croatian law. ${ }^{112}$

EU Directives are a part of the secondary legislation of the European Union adopted pursuant to regulations from the Treaties or primary legislation. The Founding Treaty in force since 2009 is the Lisbon Treaty and it consists of two separate treaties: The Treaty of the European Union and the Treaty on the Functioning of the European Union. ${ }^{113}$ Directives are proposed by the European Commission and are adopted jointly by: the Council of Ministers (hereinafter: the Council) and the European Parliament. ${ }^{114}$

The final directive from the area of combating money laundering and terrorist financing was adopted on 20 May 2015 under (EU) No. 2015/849 pursuant to Article 114 of the Treaty on the Functioning of the European Union. The process of the adoption of directives shows the importance of the European Commission, the Council and the European Parliament.

\footnotetext{
${ }^{104}$ Terrorist Financing: FATF Report to G20 Leaders - actions being taken by the FATF (2015).

${ }^{105}$ Emerging Terrorist Financing Risks (2015).

${ }^{106}$ Money laundering and terrorist financing risks and vulnerabilities associated with gold (2015).

${ }^{107}$ Financing of the Terrorist Organization Islamic State in Iraq and the Levant (2015).

${ }^{108}$ Financial flows linked to the production and trafficking of Afghan opiates (2014).

${ }^{109}$ Risk of terrorist abuse in non-profit organization (2014).

${ }^{110}$ Virtual Currencies: Key Definitions and Potential AML/CFT Risks (2014).

${ }^{111}$ Money laundering and terrorist financing through trade in diamonds (2014).

${ }^{112}$ Directive 2005/60/EC of the European Parliament and of the Council of 26 October 2005 on the prevention of the use of the financial system for the purpose of money laundering and terrorist financing.

${ }^{113}$ Consolidated versions of the Treaty on European Union and the Treaty on the Functioning of the European Union 2010/C 83/01 (2010).

${ }^{114}$ Vujičić (2011) at p. 116.
} 


\section{MONEYVAL}

The Council of Europe, which promotes values of respect for the rule of law, human rights and democracy among its 47 members, ${ }^{115}$ also includes a permanent monitoring body called the Committee of Experts on the Evaluation of Anti-Money Laundering Measures and the Financing of Terrorism MONEYVAL (as previously abbreviated: MONEYVAL). It mostly has a monitoring role, and its scope of work includes the evaluation of AML/CFT measures.

MONEYVAL does not publish official recommendations, but rather makes suggestions to Members States on how to improve and promote their AML/CFT system. Since terrorist financing has a turbulently changeable character, MONEYVAL analyses this area and publishes typologies.

Apart from its monitoring function, MONEYVAL is also a research body informing and warning the public about possible new threats in the area. In its work, MONEYVAL cooperates not only with the FATF and regional bodies originating from the FATF, but also with the International Monetary Fund, World Bank, UN and EU. The fifth round of country evaluations was initiated in 2015 in order to analyse and assess regulatory changes pursuant to Recommendations of 2012 as well as methods of their legal and operative implementation.

MONEYVAL performs evaluations in several countries: the Council of Europe members which are not FATF members or the Council of Europe members which became FATF members, but still want their assessments to be performed by MONEYVAL experts (this category currently consists of 28 countries, including Republic of Croatia), States which are not a part of the Council of Europe (Israel), Vatican, Guernsey, Jersey and Isle of Man, and Gibraltar.

The MONEYVAL Member State delegation has 3 members: experts in the area of legal regulations or AML/CFT monitoring, representatives of the Office for Anti-Money Laundering/Counter-Terrorist Financing, and experts from the individual countries' Ministry of Justice.

\section{Egmont Group}

The Egmont Group is an association, i.e., an informal network of AntiMoney Laundering and Counter-Terrorist Financing Offices (hereinafter: the Office) from the entire world and it has 151 members. ${ }^{116}$ It was founded in 1995 and was named after the building where the first meeting was held (Egmont Arenberg Palace in Brussels). ${ }^{117}$ It was founded as an informal group for international cooperation and the Egmont Group members regularly exchange

\footnotetext{
${ }^{115}$ The Council of Europe was founded in 1949 by ten countries, namely: Belgium, Denmark, France, Ireland, Italy, Luxembourg, the Netherlands, Norway, Sweden and the United Kingdom.

${ }^{116}$ The Egmont Group.

${ }^{117}$ Kovač Klemar (2012) at p. 21.
} 
information and data regarding suspicions transactions and organise joint training programmes. ${ }^{118}$

New FATF Recommendations further increased the Egmont Group's significance since the Recommendations emphasise the importance of information exchange, especially among the Egmont Group members Offices. ${ }^{119}$ The Egmont Group increases the speed and quality of information exchange among the Offices via its protected network ${ }^{120}$ and protected encrypted emails. In order to ensure legitimate exchange of information, the Offices sign a Memorandum of Understanding.

Apart from exchanging information, using a safety network for the exchange of emails and training, the Egmont Group's plan for the near future is to also increase cooperation on the operative level among individual Offices' specific departments and initiate the Offices' full independence.

\section{Institutions and Organisations Partly dealing with Terrorist Financing Prevention}

The World Bank and International Monetary Fund have been contributing to the prevention of terrorist financing by providing research and analyses, raising awareness of the AML/CFT issues, and organising projects, training and technical assistance.

In March of 2014, the Executive Council of the International Monetary Fund adopted the Combating the Financing of Terrorism Strategy and in May of the same year it was decided that the operation of the donor fund for training resources in the development of an anti-money laundering and counter-terrorist financing system in the International Monetary Fund Member States would be extended for another five years. Amount of \$20 million were allocated for the five-year period and 17 projects have already been initiated. The International Monetary Fund provides annual technical assistance and training in the field of combating money laundering and terrorist financing worth 6.6 million US dollars in 30 countries. $^{121}$

Guidelines for the prevention of terrorist financing are issued by professional organisations such as Basel Committee on Banking Supervision, International Association of Insurance Supervisors and International Organisation on Securities Commissions.

\section{Conclusion}

In the early 1990s, and especially following September 11, 2001, the issue of terrorist financing was given higher priority. The escalation of terrorism led

\footnotetext{
${ }^{118}$ Republic of Croatia became a member of the Egmont Group in 1998.

${ }^{119}$ Cindori (2008) at p. 199.

${ }^{120}$ Cindori (2007) at p. 68.

${ }^{121}$ International Monetary Fund Factsheet (2015) at p. 3.
} 
to the necessity to legally regulate this subject matter within the framework of EU and its implementation into local legislation, but also to establish associations dealing exclusively with AML/CFT, strengthening the importance of the FATF, MONEYVAL and Egmont Group.

UN Resolutions and EU Directives are not static regulations, therefore the adoption of new legal standards as a reaction to new terrorist financing modalities (due to the increased use of the Internet and Internet technologies), transformation of terrorist organisations (the founding of ISIL) and the ever more prominent issue of terrorist asset freezing is expected in the foreseeable future.

Simplifying the system of freezing assets is possible through a more detailed elaboration of bylaws. While terrorist assets in credit institutions are still relatively easily frozen thanks to an elaborate system of freezing accounts to initiate foreclosure proceedings, the problem emerges when other forms of assets, such as real estate, movable assets, securities, etc., need to be frozen.

Keeping in minds that each system is as strong as its weakest link, it is necessary to aim at a more intense cooperation among institutions and continuous growth of the AML/CFT system's legal framework. Unfortunately, it is obvious that some countries have yet to establish an adequate system for preventive measures implementation, which means that more efficient sanctioning methods need to be found.

Regardless of the AML/CFT measure implementation quality within the framework of national legislation and monitoring by numerous organisations and associations, which surely plays an important part in detecting terrorism financing and making it more difficult, due to the ideological orientation and flexibility of terrorist organisations, terrorism can only be reduced and not eradicated completely. This is why, when discussing terrorist financing prevention, we should focus on the States' efforts towards reducing the use of financial and non-financial systems of specific countries for terrorist financing as much as possible.

\section{References}

American Bar Association (2010). Voluntary Good Practices Guidance for Lawyers to Detect and Combat Money Laundering and Terrorist Financing. http://www.ameri canbar.org/content/dam/aba/publishing/criminal_justice_section_newsletter/crim just_taskforce_gtfgoodpracticesguidance.authcheckdam.pdf

Anti-Money Laundering and Terrorist Financing Law, Official Gazette No. 87/08, 25/12.

Amos, Y. (1983). 'United Nations Resolutions against International Terrorism', in Terrorism: An International Journal, Vol. 6(3): 503-517.

Banićević, N. (2013). Međunarodno pravni i institucionalni aspekti borbe protiv terorizma, at http://skalaradio.com/2013/02/13/mr-nikola-banicevic-medunarodno -pravni-iinstitucionalni-aspekti-borbe-protiv-terorizma/

Biersteker, T.J., Eckert, S.E., \& P. Romaniuk (2008). 'International initiatives to combat the financing of terrorism', in Countering the Financing of Terrorism (Biersteker, T. J., Eckert, S., E., ed.), Routledge, Oxford, UK

Bilandžić, M. (2014). Sjeme zla: uvod u studije terorizma, Despot Infinitus, Zagreb, Republic of Croatia. 
Cindori, S. (2007). 'Sustav sprječavanja pranja novca', in Financijska teorija i praksa Vol. 31/1: 55-72.

Cindori, S. (2008). 'Organizacija financijsko-obavještajnih jedinica za sprječavanje pranja novca', in Hrvatska javna uprava, Vol. 8(1): 171-203.

Combs, C.C (2006). Terrorism in the Twenty-First Century, Pearson, London, UK.

Consolidated versions of the Treaty on European Union and the Treaty on the Functioning of the European Union. 2010/C 83/01 2010. OJ C 83, 30.3.2010, p. 1-388.

Council Framework Decision of 13 June 2002 on combating terrorism. 2002 OJ L 164, 22.6.2002, pp. 3-7.

Counter-terrorism Implementation Task Force, at https://www.un.org/counterterrori $\mathrm{sm} / \mathrm{ctitf} / \mathrm{en} /$ working-groups

Criminal Code, Official Gazette, No. 125/11, 144/12, 56/15, 61/15.

Directive 2005/60/EC of the European Parliament and of the Council of 26 October 2005 on the prevention of the use of the financial system for the purpose of money laundering and terrorist financing 2005 OJ L 309, 25.11.2005, p. 15-36.

Directive (EU) 2015/849 of the European Parliament and of the Council of 20 May 2015 on the prevention of the use of the financial system for the purposes of money laundering or terrorist financing, amending Regulation (EU) No 648/2012 of the European Parliament and of the Council, and repealing Directive 2005/60/EC of the European Parliament and of the Council and Commission Directive 2006/ 70/EC. 2015 OJ L 141, 5.6.2015, p. 73-117.

Durrieu, R. (2013). Rethinking Money Laundering \& Financing of Terrorism in International Law: Towards a New Global Legal Order, Martinus Nijhoff Publishers, Leiden, Netherlands.

Egmont Group, at http://www.egmontgroup.org

Emerging Terrorist Financing Risks. 2015 Financial Action Task Force. Available at: http://www.fatf-gafi.org/documents/documents/emerging-terrorist-financing-risks. html

Financial flows linked to the production and trafficking of Afghan opiates. 2014 Financial Action Task Force. Available at: http://www.fatf-gafi.org/media/fatf/ documents/ reports/Financial-flows-linked-to-production-and-trafficking-of-afghan-opiates.pdf

Financing of the Terrorist Organisation Islamic State in Iraq and the Levant. 2015 Financial Action Task Force. Available at: http://www.fatf-gafi.org/documents/ documents/financing-of-terrorist-organisation-isil.html

FATF IX Special Recommendations. 2001 Financial Action Task Force at www.fatfgafi.org/recommendations

Green, L.C. (1979). 'Double Standards in the United Nations: The Legalization of Terrorism', Archive des Völkerrechts, Vol. 18, No. 2, p. 129-148.

Home/United Nations, at http://www.un.org

International Monetary Fund Factsheet. 2015 International Monetary Fund, Washington D.C. International standards on combating money laundering and the financing of terrorism \& proliferation, The FATF Recommendations. 2012 Financial Action Task Force.

Johnson, C.M. (2000). 'Introductory Note to the International Convention for the Suppression of the Financing of Terrorism', in International Legal Materials, Vol. 39(2): 268-269.

Joyner, C.C. (2004). 'The United Nations and Terrorism: Rethinking Legal Tensions between National Security, Human Rights, and Civil Liberties', in International Studies Perspectives, No. 5, pp. 240-257.

Kalinić, P. (2003). Teror i terorizam, Naklada Jesenski i Turk, Zagreb, Republic of Croatia. 
Kalliopi, K. (2006). 'The UN, Human Rights and Counter-Terrorism', in International Cooperation in Counter-terrorism: The United Nations and Regional Organisations in the Fight against the Terrorism (Nesi, G., ed.), Ashgate, Oxford, UK.

Ratification of International Convention for the Suppression of the Financing of Terrorism, Official Gazette, International Agreements, No. 16/03.

Kovač Klemar, T. (2012). Modaliteti financiranja terorizma, Master thesis, Faculty of Political Science of Zagreb University, Zagreb, Republic of Croatia.

Levitt, M. (2002). 'The Political Economy of Middle East Terrorism', in Middle East Review of International Affair, Vol. 6(4): 49-65.

Mathers, C. (2004). Crime School: Money Laundering: True Crime Meets the World of Business and Finance, Key Porter Books Limited, Toronto, Ontario, Canada.

Merriman, J. (2009). Was this man the first terrorist of the modern age? http://news. bbc.co.uk/2/hi/8263858.stm

Money laundering and terrorist financing risks and vulnerabilities associated with gold. 2015 Financial Action Task Force. At http://www.fatf-gafi.org/publications/met hodsandtrends/documents/ml-tf-risks-and-vulnerabilities-gold.html

Money laundering and terrorist financing through trade in diamonds. 2014 Financial Action Task Force. At http://www.rubel-menasche.com/industry/fair-trade/mo ney-laundering-and-terrorist-financing-through-trade-in-diamonds-fatf/

Pearl, R. (2007). '9/11 Implications for U. S. Policy Makers', in J.K.Giraldo \& H.A. Trinkunas (eds.) Terrorism Financing and State Responses - A Comparative Perspective. Stanford University Press, Redwood City, California, USA.

Pedić, Ž. (2012). 'Odnos međunarodnoga i europskoga pravnog okvira za suzbijanje terorizma', in Zagrebačka pravna revija, No. 1, pp. 57-80.

Ratification of the Charter of the United Nations, Official Gazette, International Agreements, No. 15/93.

Proulx, V. (2012). Transnational Terrorism and State Accountability, Hart Publishing, Haywards Heath, Sussex, UK.

Raphaeli, N. (2003). 'Financing of Terrorism: Sources, Methods, and Channels', in Terrorism and Political Violence, Vol. 15(4): 59-82.

Risk of terrorist abuse in non-profit organisation. 2014 Financial Action Task Force. At http://www.fatf-gafi.org/media/fatf/documents/reports/Risk-of-terrorist-abusein-non-profit-organisations.pdf

Romanov, V.A. (1990). 'The United Nations and the problem of combatting international terrorism', in Terrorism and Political Violence, Vol. 2(3):289-304.

Saul, B. (2006). 'The Legal Response of the League of Nations to Terrorism', in Journal of International Criminal Justice, Vol. 4(1): 78-102.

Simser, J. (2011). 'Terrorism financing and the threat to financial institutions', in Journal of Money Laundering Control, Vol. 14(4): 334-345.

Smjernice u svezi s postupanjem na području borbe u suzbijanju financiranja terorizma (2011). Anti-Money Laundering Office, Zagreb, p. 1-2.

Stiles, K.W. and A. Thayne (2006). 'Compliance with International Law: International Law on Terrorism at the United Nations' in Cooperation and Conflict: Journal of the Nordic International Studies Association, Vol. 41(2): 153-176.

Terrorist Financing: FATF Report to G20 Leaders - actions being taken by the FATF. 2015 Financial Action Task Force, at http://www.fatf-gafi.org/publications/fatfre commendations/documents/terrorist-financing-fatf-report-to-g20.html

UN Charter. http://www.un.org/en/charter-united-nations/index.html

Virtual Currencies: Key Definitions and Potential AML/CFT Risks. 2014 Financial Action Task Force at http://www.fatf-gafi.org/media/fatf/documents/reports/Vir tual-currency-key-definitions-and-potential-aml-cft-risks.pdf 
Vujičić, T. (2011). Sekundarno zakonodavstvo Europske Unije, in Hrvatska pravna revija, 2011, pp. 116-117.

Zacząć działać już z dostawcami loterii on-line w Internecie - Tu trzeba uważać, at http://www.fatf-gati.org; http://www.fatf-gafi.org/publications/high-riskandnoncooperativejurisdictions $/ ? \mathrm{hf}=10 \& \mathrm{~b}=0 \& \mathrm{~s}=\mathrm{desc}$

\section{UNITED NATIONS GENERAL ASSEMBLY RESOLUTIONS:}
A/RES 3034 (XXVII 1972)
A/RES 31/102 (1976)
A/RES 32/147 (1977)
A/RES 34/145 (1979)
A/RES 38/130 (1983)
A/RES 39/159 (1984)
A/RES 40/61 (1985)
A/RES 42/159 (1987)
A/RES 49/60 (1994)
A/RES 51/210 (1996)
A/RES 53/108 (1999)
A/RES 54/109 (1999)
A/RES 55/108 (1999)
A/RES 60/1 (2005)
A/RES 60/288 (2006)
A/RES 62/71 (2008)
A/RES 62/272 (2008)
A/RES 64/177 (2010)
A/RES 64/235 (2010)
A/RES 64/297 (2010)
A/RES 66/178 (2011)
A/RES 66/282 (2012
A/RES 68/119 (2013)
A/RES 68/276 (2014). 


\section{UNITED NATIONS SECURITY COUNCIL RESOLUTIONS:}

S/RES 1044 (1996)

S/RES 1267 (1999)

S/RES 1333 (2000)

S/RES 1363 (2001)

S/RES 1373 (2001)

S/RES $1456(2003)$

S/RES 1526 (2004)

S/RES 1535 (2004)

S/RES 1566 (2004)

S/RES 1617 (2005)

S/RES 1624 (2005)

S/RES 1730 (2006)

S/RES 1735 (2006)

S/RES 1805 (2008)

S/RES 1822 (2008)

S/RES 1904 (2009)

S/RES 1963 (2010)

S/RES 1988 (2011)

S/RES 1989 (2011)

S/RES 2082 (2012)

S/RES 2083 (2012)

S/RES 2129 (2013)

S/RES 2133 (2014)

S/RES 2160 (2014)

S/RES 2161 (2014)

S/RES 2170 (2014)

S/RES 2178 (2014)

S/RES 2199 (2015)

S/RES 2242 (2015)

S/RES 2253 (2015). 
